\title{
The Aptian Gura Râului conglomerates (Southern Carpathians): remains of an extended subaqueous gravity flow deposit from the eastern flank of the Getic Nappe
}

\author{
Răzvan UNGUREANU ${ }^{1}$, Emanoil SĂSĂRAN ${ }^{1,2}$, Ioan I. BUCUR ${ }^{1,2}$, Cristian Victor MIRCESCU ${ }^{1, *}$, \\ Alexandra UNGUREANU ${ }^{1}$ and Ciprian Gheorghi ă UNGUR ${ }^{1}$ \\ 1 Babeş-Bolyai University, Department of Geology, 1, M. Kogălniceanu, 400084, Cluj-Napoca, Romania \\ 2 Babeş-Bolyai University, Department of Geology and Center for Integrated Geological Studies, 1, M. Kogălniceanu, \\ 400084, Cluj-Napoca, Romania
}

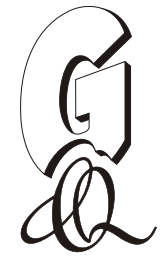

\begin{abstract}
Ungureanu, R., Săsăran, E., Bucur, I.I., Mircescu, C.V., Ungureanu, A., Ungur, C.G., 2019. The Aptian Gura Râului conglomerates (Southern Carpathians): the last remains of an extended subaqueous gravity flow deposit from the eastern flank of the Getic Nappe. Geological Quarterly, 63 (1): 88-105, doi: 10.7306/gq.1459
\end{abstract}

Associate editor: Wojciech Granoszewski

The Getic Nappe belongs to the Central Dacides or Dacia Mega Unit. Gravity flow deposits were generated by the Lower Cretaceous overthrust and uplift of this unit over the External Dacides. In the Piatra Craiului Syncline (part of the Getic Nappe), such detrital deposits are represented by the Aptian conglomerates and the uppermost Albian-Cenomanian conglomerates. Part of the infill of the syncline consists of a thick pile of NW-SE oriented conglomerates. Sedimentological study documents the presence of an association which consists of three distinct facies types, represented by: massive conglomerates; alternating conglomerates, sandstones and microconglomerates; and fining- and coarsening-upwards conglomerates. These deposits were accumulated through a series of debris flows, and hyperconcentrated or concentrated flows. The entire assemblage represents a complex routing system within submarine channels, an interpretation made by interpreting facies associations, palaeoflow directions and clast fabrics. A large part of this succession was removed by post-Albian erosion. Thus, the interpretation of the depositional system could be as a series of feeder channels or the submarine sector of a fan-delta system representing a foreland basin fill.

Key words: conglomerates, gravity flow deposits, fan-deltas, Lower Cretaceous, Piatra Craiului Massif, Romania.

\section{INTRODUCTION}

Studies of conglomeratic deposits grew with the development of the first accurate facies models (e.g., Walker and Mutti, 1973; Walker, 1975; Aalto, 1976; Lowe, 1982). Similar papers published in the last few decades deal mainly with the interplay between alluvial-fluvial continental and submarine deposits and the adjacent basins incorporating them (e.g., Ethridge and Wescott, 1984; Surlyk, 1984; McPherson et al., 1987; Higgs, 1990; Postma, 1990; Sohn et al., 2002; Bernhardt et al., 2011). These types of deposits form extensive outcrops in Romania but their study is still incipient. Special attention has been given by various authors to the Bucegi conglomerates (Patrulius,

* Corresponding author, e-mail:

cristianvictormircescu@hotmail.com

Received: May 17, 2018; accepted: November 27, 2018; first published online: March 22, 2019
1969; Stanley and Hall, 1978; Briceag et al., 2009; Jipa et al., 2013; Olariu et al., 2014) while other detrital deposits (e.g., the Ceahlău conglomerates) have been studied to a lesser extent (Grasu et al., 1996). The infill of the Piatra Craiului Syncline includes the Aptian Gura Râului and the uppermost Albian-Cenomanian conglomerates.

The main objective of this study is to describe in detail the depositional and sedimentological features of the Aptian Gura Râului conglomerates by integrating content analysis and pebble provenance description methods. The grain flow deposits containing carbonate pebbles are studied in order to decipher the geodynamic history of their source area (Kostaki et al., 2013; Gawlick and Missoni, 2015; Strzeboński et al., 2017; Gawlick et al., 2017).

In this work we describe in detail the sedimentological features of the Aptian Gura Râului conglomerates and to present several hypotheses concerning their depositional environment . We also explain the interplay between tectonics and depositional processes on the eastern margin of the Getic Nape during the Early Cretaceous, given that tectonic motions are usually reflected in foreland basin fills (DeCelles et al., 1991; Fielding et al., 2007; Olariu et al., 2014; Gawlick et al., 2018). 


\section{GEOLOGICAL SETTING}

\section{RESEARCH BACKGROUND}

The Piatra Craiului Massif forms a NW-SE oriented mountain range $25 \mathrm{~km}$ long in the northeastern part of the Southern Carpathians (Fig. 1). The sedimentary succession contains Middle Jurassic, Upper Jurassic and Lower Cretaceous rocks which directly overlie the metamorphic basement of the Cumpăna and Leaota units (Oncescu, 1943; Gherasi, 1962; Popescu 1966; Gherasi et al., 1966). The entire succession comprises Middle Jurassic-Oxfordian siliciclastic and carbonate rocks and radiolarites (Popescu, 1966; Patrulius, 1969; Bucur, 1978, 1980; Meszaros and Bucur, 1980; Patrulius et al., 1980; Beccaro and Lazăr, 2007), 1200 m thick Kimmeridgian-Upper Valanginian carbonates (Ungureanu et al., 2015 and references therein) and Aptian to uppermost Albian-Cenomanian siliciclastic rocks (Popescu, 1966; Patrulius, 1969; Fig. 1A, B). Middle Jurassic sediments were deposited in a transgressive context. By contrast, the Kimmeridgian-Lower Valanginian succession forms a large regressive megasequence (Bucur et al., 2009; Pleş et al., 2013; Mircescu et al., 2014). A sedimentary hiatus marks the transition into Upper Valanginian carbonate debris flows and hemipelagic deposits (Grădinaru et al., 2016). The final part of the sedimentary succession contains Aptian-Cenomanian conglomerates (Ungureanu et al., 2015).

\section{TECTONIC FRAMEWORK}

The Piatra Craiului Massif forms an integral part of a larger tectonic unit which is known in the geological literature as the Getic Nappe (Murgoci, 1905, 1910; Săndulescu, 1984; Fig. $1 C)$. This unit is included in a larger group of major tectonic units which form the Median Dacides (Săndulescu, 1984) or the Dacia Mega-Unit (cf. Csontos and Vörös, 2004). Their genesis is strongly related to Jurassic rupture events (Săndulescu, 1984, 1994). The Neo-Tethys ocean was located between the Tisza and Dacia megablocks. Its latest Jurassic-Early Cretaceous closure (Ma enco et al., 2010) was followed by Cretaceous continental collision (Schmid et al., 2008). This moment coincides with the development of the Getic Nappe as a major unit within the Southern Carpathians (Săndulescu, 1984). The structural evolution of the Getic Nappe is defined by several tectonic events. These are represented by Upper Barremian-Lower Cenomanian, Coniacian-Maastrichtian (Codarcea, 1940; Săndulescu, 1984) and Upper Turonian-Coniacian movements (cf. Schmid et al., 2008). The first event is marked by the overthrust of the Getic Nappe front over the External Dacides (Codarcea, 1940; Săndulescu, 1984). In this context, the central part of the Leaota region evolved as a large anticline which was bordered by the Bucegi Syncline on its eastern side. The Piatra Craiului Syncline was located on its western side. Limestones and conglomerates were deposited in the Dâmbovicioara Couloir. This structural unit separated two uplifted areas (Patrulius, 1969). The second Cretaceous tectonic event was marked by the final overthrust of the Getic Domain over the Danubian one (Săndulescu, 1984). The last major tectonic events are related to post-Paleogene movements. Paleogene-Miocene parallel extension, dextral and fault-related transtentional movements define this tectonic stage. Older ruptural accidents were reactivated. As a result, the Piatra Craiului Massif became an overthrown flank of a partially covered fold (Popescu, 1966).
Jekelius (1916) indicated for the first time the presence of uppermost Albian-Cenomanian conglomerates in the Piatra Craiului Massif. Later Popescu (1966) and Patrulius (1969) distinguished two distinct packages of conglomerate deposits: the Upper Aptian Gura Râului conglomerates and the Vraconian (Upper Albian)-Cenomanian conglomerates (Fig. 1A).

Popescu (1966) described the stratotype of the Upper Aptian Gura Râului conglomerates from the NE part of the Piatra Craiului Massif. Patrulius (1969) attributed to them an Upper Aptian age by comparing these deposits with large blocks from the general mass of the middle-upper Albian Bucegi conglomerates (e.g., Piatra Arsă, Babele, Obârşia). The matrix of these megaclasts contains abundant benthic foraminifera (orbitolinids) (Popescu, 1966; Patrulius, 1969). Wellrounded carbonate pebbles (2-10 centimetres in diameter) dominate the lithological spectrum.

In the northern part of the syncline, the uppermost Albian-Cenomanian conglomerates directly overlie the Aptian Gura Râului conglomerates (Fig. 1D). They are hosted in a carbonate-rich sandy matrix (Popescu, 1966; Patrulius, 1969). Their age was inferred by comparing these deposits with similar, Upper Albian-Cenomanian ammonite-bearing conglomerates from the Dâmbovicioara Zone (Toula, 1897; Simionescu, 1897; Popovici-Haţeg, 1898) and the northern part of the Ghimbavu Mountain (Patrulius and Dimitriu, 1962). The general mass of these conglomerates contains interbedded massive carbonate breccias, metre-scale limestone olistoliths (Popescu, 1966) and rare metamorphic blocks (Ungureanu et al., 2017).

Ungureanu et al. (2015) studied the contact between the basal part of these conglomerates and the overlying Tithonian-Lower Valanginian carbonate succession from the Piatra Craiului Massif. This study highlights similarities between elements of these conglomerates and analogue components from the Gura Râului outcrop. The same paper describes in detail the breccias and conglomerates from the basal part of the Gura Râului conglomerates. Their matrix contains orbitolinid-rich associations which indicate an Upper Aptian age.

Ungureanu et al. (2017) identified possible source areas for the Piatra Craiului conglomerate deposits by describing in detail their clast lithology, clast morphometry and palaeoflow directions. Matrix and pebble lithological analysis indicates the following particularities for the Aptian Gura Râului conglomerates:

Carbonate pebbles are dominant (79\%). By contrast, metamorphic and siliceous pebbles are scarce (16 and 5\% respectively). The metamorphic pebbles were sourced from the Cumpăna and Leaota metamorphic groups (gneisses, quartzitic schists, quartzites, sericite-quartzite schists and sericite-chlorite schists). The siliceous pebbles were sourced from Oxfordian radiolarites. Carbonate material was sourced from Middle Jurassic (?Bajocian-Lower Callovian)-Lower Cretaceous (Barremian-Aptian) deposits. They include siliciclastic, shallow-water and deep-water pelagic facies types. Upper Tithonian-Lower Valanginian carbonate pebbles are dominant (Ungureanu et al., 2017). Their source area corresponds roughly with the N-NW proximities of the Piatra Craiului Massif. These adjacent areas were once covered by a thick pile of carbonates. Such sediments were probably completely eroded during the Cretaceous tectonic events. One exception is represented by the Codlea region where carbonates form the sedimentary cover of the metamorphic basement. This region represents the only existing source area where carbonate deposits form good outcrops. 

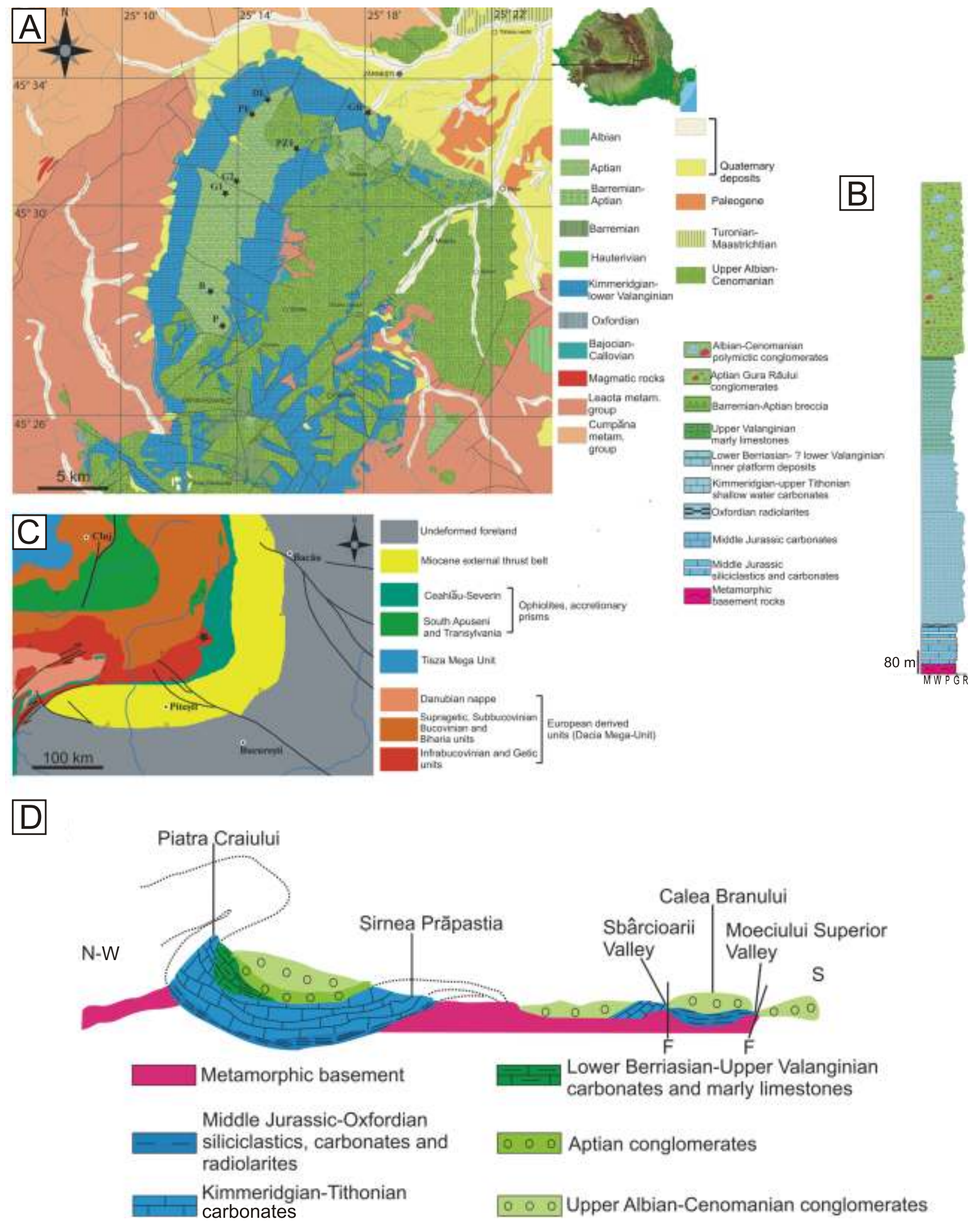

Fig. 1. Location of the study area

A - geological map of the region (1:50 000) and the study areas (GR - Gura Râului; PZ1 - Prăpăstiile Zărneştilor; DL - Drumul lui Lehman; PF - Padinile Frumoase; G1, G2 - Grind; B - Brusturet; P - Pietricica (redrawn from Dimitrescu et al., 1971; Patrulius et al., 1971; Săndulescu et al., 1972; Dimitrescu et al., 1974, with slight changes); B - synthetic column of the sedimentary succession from the Piatra Craiului Massif, from Ungureanu et al. (2017); C - excerpt from the tectonic map of the Alps, Carpathians and Dinarides, redrawn from Schmid et al. (2008); D - geological cross-section through the northern part of the Piatra Craiului Massif and Bran Pass (redrawn from Jekelius, 1938, with minor changes) 
The same methodology was used to identify the source area of the uppermost Albian-Cenomanian conglomerates. According to Ungureanu et al. (2017) carbonate pebbles are dominant ( 88\%) while metamorphic and siliceous clasts are scarce. Microfacies and micropalaeontological analysis performed on carbonate pebbles indicate a Middle Jurassic-Lower Cretaceous source area for the conglomerates (Ungureanu et al., 2017). The olistoliths are derived from Upper Tithonian-Lower Valanginian carbonate deposits and are share similar characteristics with the same deposits from the Piatra Craiului Massif (Bucur et al., 2013).

\section{METHODOLOGY}

Decimetre- to metre-scale outcrops were studied over 4 years in seven representative locations: Gura Râului, Prăpăstiile Zărneştilor, Padinile Frumoase, Drumul lui Lehman, Refugiul Grind, Cabana Brusturet and Pietricica (Figs. 1A and 2). Field analysis techniques involved general exposure observations. They include bed thickness measurements, construction of detailed sedimentological logs, textural analysis (imbrication and bedding dip measurements), clast morphometry, lithology observations and high-resolution panoramic photographs. The entire dataset was correlated and synthesized in order to build the best picture of the entire Aptian conglomerate succession.

\section{RESULTS}

The Aptian conglomerates cover an outcrop surface which is $10 \mathrm{~km}$ long and $3 \mathrm{~km}$ wide. They stretch from NE (Gura Râului Chalet) and East (Bran area) towards SE (Pietricica), parallel with the massif's crest, covering the entire syncline area (Fig. 1A). This Aptian detrital succession directly overlies the Upper Valanginian marly limestones. It is composed of vertically stacked successions of carbonate polymictic breccias $\left(\begin{array}{ll}1-3 & \mathrm{~m}\end{array}\right)$, polymictic carbonate ortho/paraconglomerates (15-30 m) and polymictic paraconglomerates ( 200 m) (Fig. 1B).

\section{CARBONATE POLYMICTIC BRECCIAS $(1-3 \mathrm{~m})$}

Description. The first detrital episode spans the entire carbonate succession from the Piatra Craiului Massif. It consists of grain-supported brecciated deposits of variable thickness with a carbonate-rich muddy matrix (Fig. 3A). Pebbles show variable dimensions (between $0.1-5 \mathrm{~cm}$ ) and a range of angular to subrounded shapes (Fig 3A). Components are very poorly sorted. The clasts and matrix have a dominant carbonate composition (more than $98 \%$ are carbonate clasts). The matrix contains very well preserved Aptian orbitolinids (e.g., Rectodictyoconus giganteus and Palorbitolina sp.) and rare quartz grains (Ungureanu et al., 2015).

Interpretation. These sediments were deposited by a series of submarine debris flows. Evidence for this includes the sedimentary features present (muddy matrix, poor sorting of the components, lack of grading, erosional base; Lowe, 1982; Nemec and Steel, 1984; Sohn et al., 2002). Shelf deposition is indicated by the abundance of well-preserved orbitolinids. The transported material was probably sourced from near to the basin. This supposition is strengthened by the following ober- vations: 1) breccia components are poorly sorted, with mostly angular-subangular-subrounded clasts; 2) carbonate clasts were sourced from Berriasian-Lower Valanginian and Barremian-Lower Aptian deposits; 3) microfacies distribution is relatively homogeneous (Ungureanu et al., 2015).

\section{POLYMICTIC CARBONATE CONGLOMERATES (15-30 m)}

Description. The brecciated succession is overlain by clast-supported polymictic carbonate conglomerates (more than $95 \%$ are carbonate clasts). Subrounded to very well rounded carbonate clasts have mean dimensions ranging from 2 to $3 \mathrm{~cm}$. They are hosted by a silty clay-rich cement (Fig. 3B). Oriented polished slabs were analysed and the resulting data was correlated with field information. Observed facies typologies include alternating sequences of moderately sorted orthoconglomerates and graded paraconglomerates with imbricated pebbles. Their matrix contains abundant orbitolinids and increased proportions of terrigenous quartz if compared with the monomictic breccia levels. The upper part of these deposits contains metamorphic or siliceous clasts together with increased proportions of terrigenous material. They show a coarsening-upwards trend.

Interpretation. These sediments were deposited by a combination of concentrated-hyperconcentrated flows (Mulder and Alexander, 2001) or high-energy turbidity currents (Lowe, 1982). This depositional model follows the original interpretation of Popescu (1966) and Patrulius (1969). Depositional features such as moderate sorting, imbrication and a coarsening-upwards trend together with matrix characteristics support this hypothesis. Shelf depositional activity was driven by a series of submarine flows since well-preserved orbitolinids are abundant. Clast morphology suggests reworking under continental conditions and probably prolonged transport periods. The diversity of clast types suggests that the main source area comprises more extensive and diverse terrain than the equivalent source area for the polymictic breccias, as indicated by the presence of rare metamorphic and siliceous pebbles; these clasts are absent in the breccia levels. In terms of microfacies and micropalaeontological composition, most of the carbonate pebbles show similar characteristics with their analogue components from the polymictic breccia levels (Ungureanu et al., 2015).

\section{GURA RÂULUI POLYMICTIC CONGLOMERATES (SENSU POPESCU, 1966) ( 200 m)}

These deposits were intensely fragmented by post-Aptian tectonic activity (Fig. 2B, C, D). They are strongly eroded and covered by vegetation (Fig. 2E). Analysis of exposures indicates the presence of stacked beds, 1 to $5 \mathrm{~m}$ thick, each with an erosional base (Fig. 2A, B, E). Depositional features include graded bedding, imbrications and channel-fill structures (Fig. 2E).

Pebble diameter ranges from 2 to $6 \mathrm{~cm}$. Subrounded to very well rounded clasts are common. The matrix contains rare orbitolinids (Fig. 4) and has a mixed clayey-sandy to silty-sandy composition. Exotic blocks were rarely identified and they contain pure carbonate material (Fig. 2F). The lithological spectrum contains carbonate, metamorphic and siliceous pebbles (Fig. 3C-F). Abundant carbonate pebbles were sourced from Middle Jurassic-Lower Cretaceous deposits. They comprise 79\% from the clast inventory (Ungureanu et al., 2017). There are good exposures at Prăpăstiile Zărneştilor, Grind, Brusturet and Pietri- 



Fig. 2. Exposures of the Aptian Gura Râului conglomerates

A, B - erosionally stacked beds from the Brusturet area; C, D - intensely fragmented outcrops from the Grind Area (C G1; D - G2); the sequence is partly overturned; E - erosionally stacked metre-thick beds (1-1.5 m) from Prăpăstiile Zărneştilor (PZ1); F - subrounded carbonate block from the Pietricica Area (P); G - channel-fill structures are marked with yellow arrows (Prăpăstiile Zărneştilor) (PZ1); in A-E erosional surfaces are indicated by dotted yellow lines 

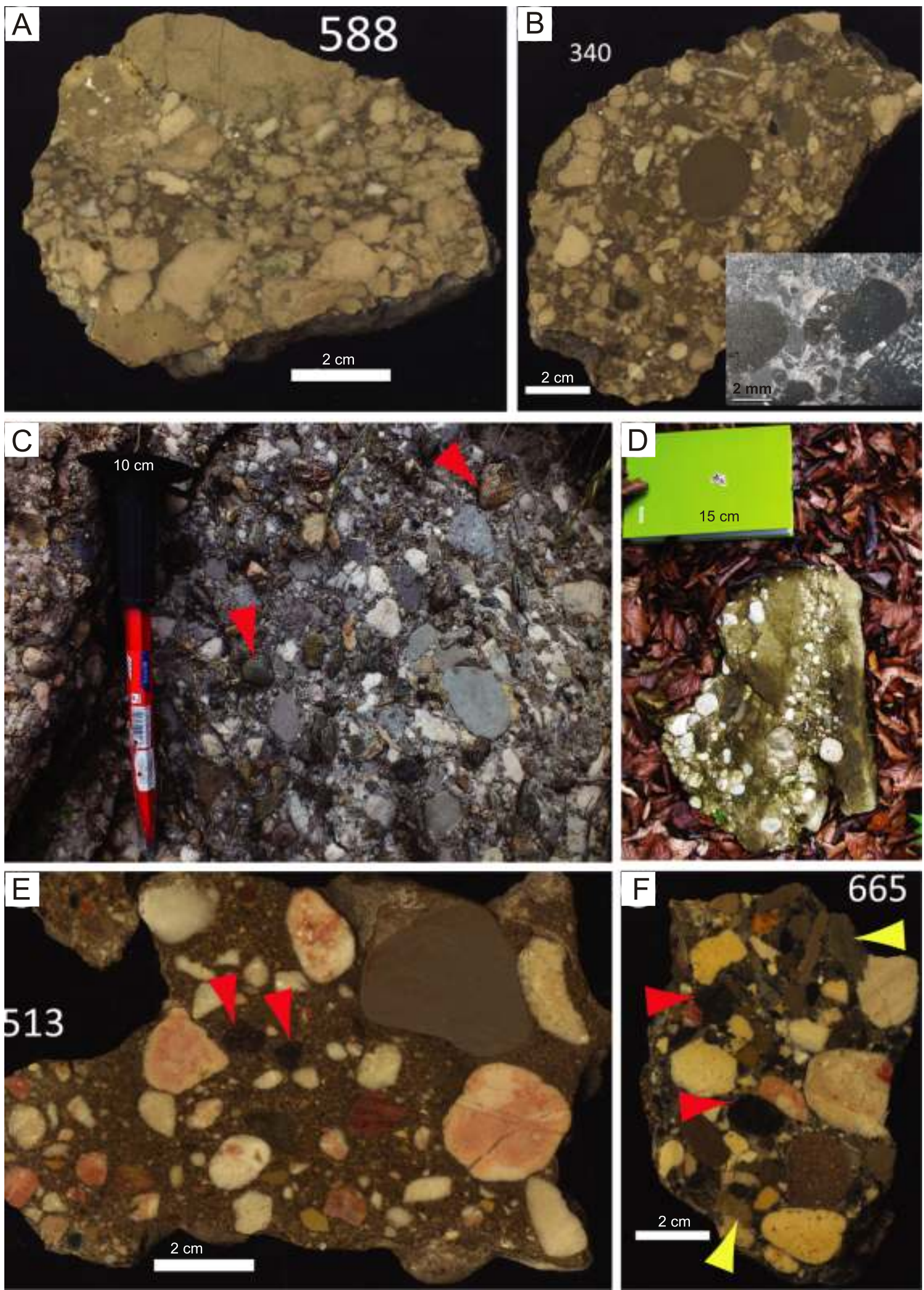

Fig. 3. General descriptive and lithological characteristics of the Gura Râului Aptian conglomerates

A - poorly sorted carbonate monomictic breccias with angular to subrounded pebbles (Drumul lui Lehman - DL); B moderately sorted carbonate monomictic conglomerates with subrounded and rounded pebbles (Padinile Frumoase PF); $\mathbf{C}$ - carbonate and metamorphic clasts (red arrows) in a granular flow (Padinile Frumoase - PF); D - fragment composed of alternating carbonate conglomerates and sandstones (Brusturet - B); $\mathbf{E}$ - well-rounded, poorly sorted pebbles (red arrow) in a sandstone matrix (Grind - G2); F - well-rolled clasts encased in a micritic-arenitic matrix with abundant ruditic clasts; carbonate pebbles are quite abundant, whereas by contrast, metamorphic (red arrows) and siliceous (yellow arrow) clasts are rare (Prăpăstiile Zărneştilor - PZ1) (A, B, E, F: scale $-2 \mathrm{~cm}$; C: chisel $-10 \mathrm{~cm}$; D: notebook $-15 \mathrm{~cm}$ length) 

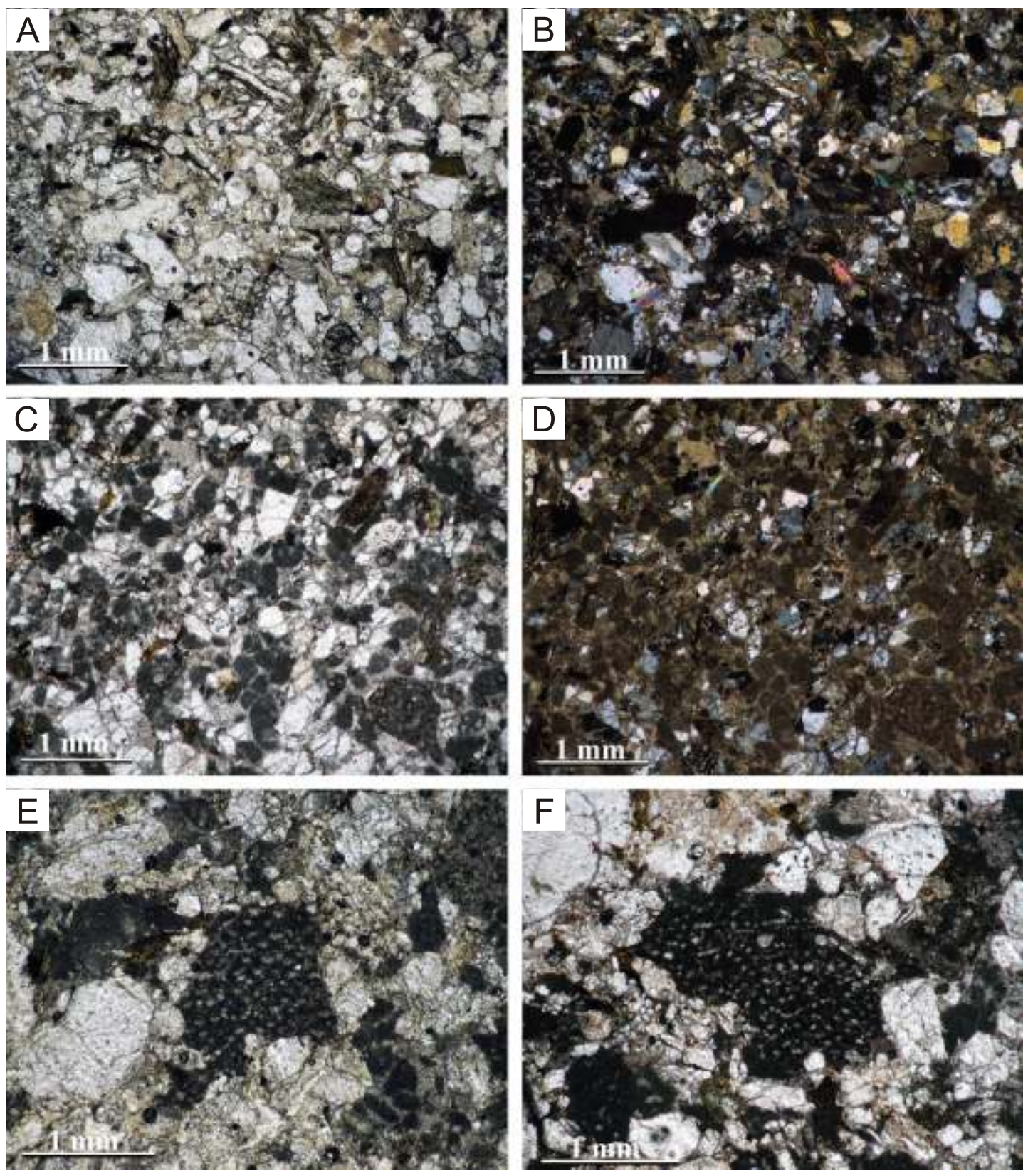

Fig. 4 Main cement types and their components

A - (1n), B - $(n+)$ quartz arenite with predominant monocrystalline quartz and rare lithic fragments (carbonates, metamorphic rocks) (Grind-G2); C - (1n), D - $(n+)$ lithic arenite containing carbonates, quartz and rare feldspars or metamorphic rock fragments (Prăpăstiile Zărneștilor - PZ1); E, F - (1n) poorly preserved orbitolinid fragments encased in a conglomeratic cement (Prapastiile Zarnestilor - PZ1) (samples: A, B - 669E; C, D, E, F - 3403)

cica. Three main facies types were described by interpreting the depositional features present. They include massive ungraded conglomerates (facies $1 ; 3-12 \mathrm{~m}$ ), graded conglomerates (facies 2; 4-15 $\mathrm{m}$ ) and alternating conglomerates and sandstones (facies 3; 2-8 m).

\section{UNGRADED CONGLOMERATES - FACIES 1} (3-12 m)

Description. This facies type is characterized by the presence of ungraded structures. Each bed contains increased pro- portions of pebbles of the same clast size (Fig. 5). Bed thickness ranges from 0.2 to $3 \mathrm{~m}$. Massive (Fig. 5A, B, D) or amalgamated beds (Fig. 5C, E) are separated by erosional surfaces (Fig. 6). The poorly sorted micritic-sandy matrix encompasses pebbles ranging from 3-6 cm while the middle to upper part of each bed contains rare, rounded or angular blocks (Fig. 6C, D). Pebble sorting ranges from moderate to good. The a axis of the elongated clasts frequently shows parallel orientation with the bedding plane or with the axis of imbrication (Figs. 5E and 6D, E). In some regions, the Aptian conglomerates form only small occurrences (e.g., Gura Râului, Padinile Frumoase, Grind). Distinctive facies features include lack of grading, frequent imbrication and the presence of rolled carbonate blocks (megaclasts). 

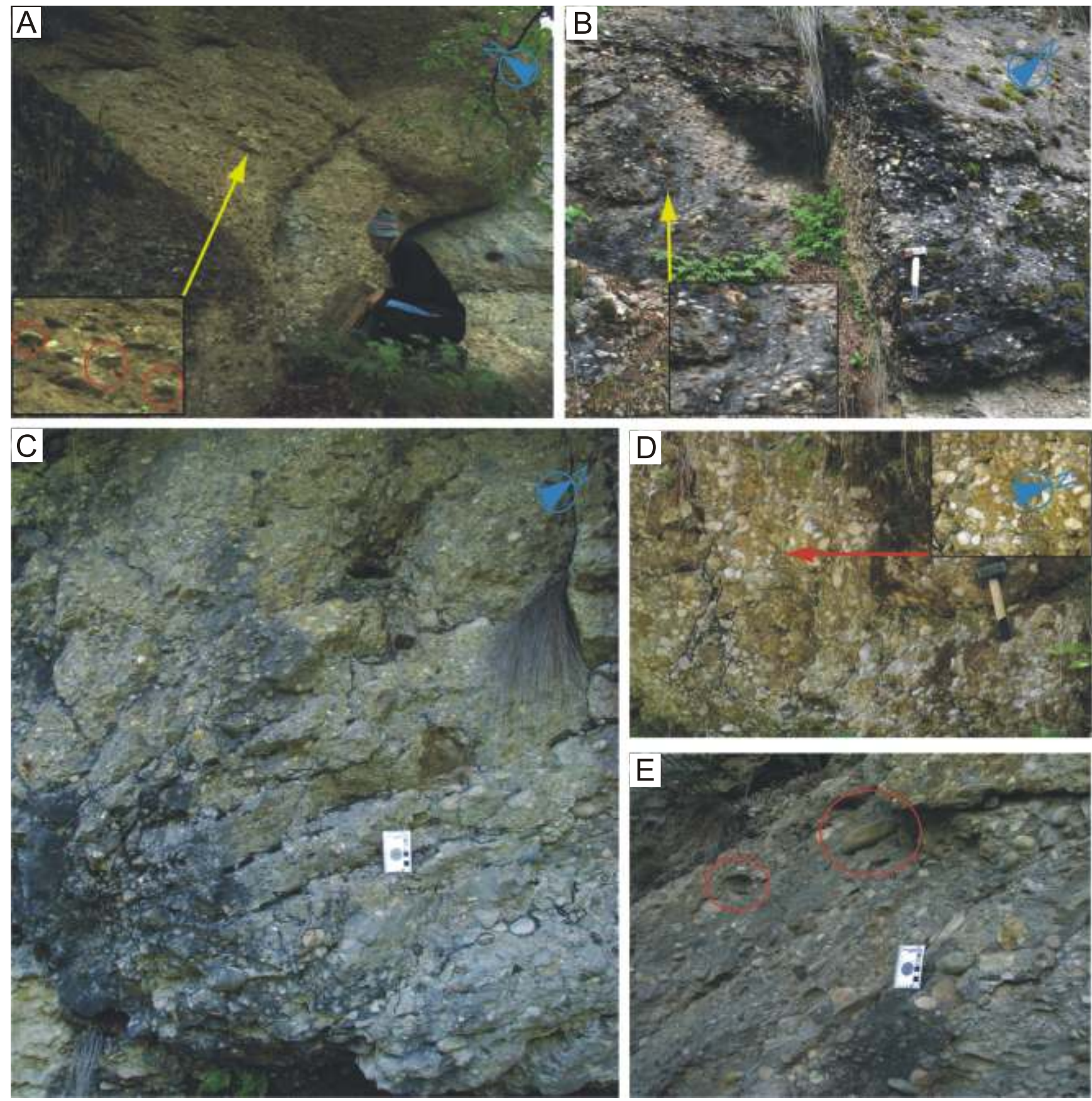

Fig. 5 Ungraded conglomerates (Facies 1)

A - high-density concentrated flows which contain imbricated clasts or clasts which are parallel with the bedding (yellow arrow-detail, imbricated pebbles are indicated by a red circle) (zona Brusturet); B - concentrated flows with high density of small equigranular pebbles (yellow arrow-detail) (Brusturet area); C, E - amalgamated structures with frequent imbricated pebbles, long the a axis (E - red circle) (Brusturet area); D - poorly to moderately sorted ungraded conglomerates; they are composed almost entirely of carbonate clasts and carbonate cement (red arrow - detail) (C - Brusturet area, D - Pietricica area)

Interpretation. These sediments were deposited by a series of high-density, non-cohesive concentrated gravity flows (Table 1 and references therein). Ungraded conglomerates are particularly known for their abundant imbrication, which is normally produced by flow particle interaction. Dispersive pressures are generated within the flow and they are responsible for imbrication development (Rees, 1968; Walker, 1975).

\section{FINING AND COARSENING UPWARD CONGLOMERATES -} FACIES $2(4-15 \mathrm{~m})$

Facies 2 is the most common in the great majority of the outcrops. It is defined by beds with coarsening-upwards structures. In rare situations, the upper part of the beds may contain interbedding with fining-upwards structures (Figs. 7 and 8). 

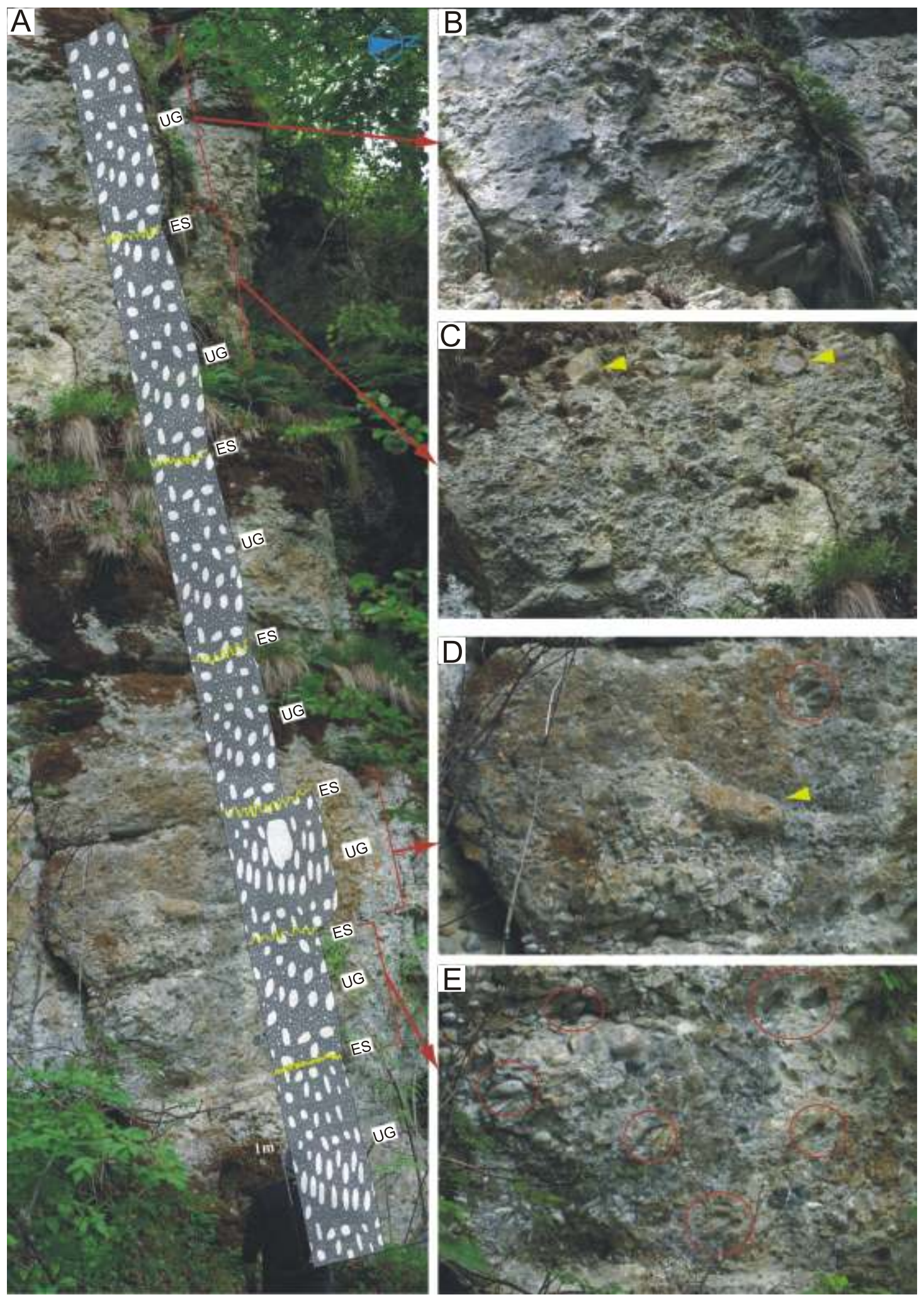

Fig. 6. Ungraded conglomerates (Facies 1 from Pietricica area)

A - succession composed of erosionally stacked, ungraded beds with frequent imbrications (UG - ungraded conglomerates; ES - erosional surface); B-E - details from A; pebble imbrication can be observed (D, E - red circled area); rare megaclasts of carbonate origin (C, D - yellow arrows) 
Relationship between facies types, sedimentary structures and depositional mechanisms

\begin{tabular}{|c|c|c|}
\hline Facies types & Depositional features & Depositional mechanisms \\
\hline Facies 1 - ungraded conglomerates & $\begin{array}{l}\text { - pebbles of same size } \\
\text { - erosional contacts } \\
\text { - imbrications } \\
\text { - carbonate blocks } \\
\text { - moderate to good sorting }\end{array}$ & $\begin{array}{l}\text { - non-cohesive concentrated gravity flows } \\
\text { (Hampton, 1975; Lowe, 1976, 1982; Mulder } \\
\text { and Alexander, 2001) }\end{array}$ \\
\hline $\begin{array}{l}\text { Facies } 2 \text { - fining and coarsening } \\
\text { upward conglomerates }\end{array}$ & $\begin{array}{l}\text { - coarsening and fining-upward structures } \\
\text { - erosional contacts } \\
\text { - imbrications } \\
\text { - poor sorting } \\
\text { - pebbles of small diameters } \\
\text { - poor sorting }\end{array}$ & $\begin{array}{l}\text { - concentrated flows (Mulder and Alexander, } \\
2001 \text { ) } \\
\text { - grain by grain mechanisms (Pickering et al., } \\
\text { 1989) } \\
\text { - high density turbidity currents (R2, R3 divi- } \\
\text { sions of Lowe, 1982) }\end{array}$ \\
\hline $\begin{array}{l}\text { Facies } 3 \text { - alternating conglomerates, } \\
\text { sandstones and microconglomerates }\end{array}$ & $\begin{array}{l}\text { - conglomerates interbeded with sandstones } \\
\text { and microconglomerates } \\
\text { - coarsening and fining-upward structures } \\
\text { - gradational and erosional contacts } \\
\text { - imbrications } \\
\text { - poor sorting } \\
\text { - carbonate blocks }\end{array}$ & $\begin{array}{l}\text { - concentrated and hyperconcentrated flows } \\
\text { (Mulder and Alexander, 2001) } \\
\text { - high density turbidity currents (R2, R3 } \\
\text { divisions of Lowe, 1982) } \\
\text { - debris flows (Lowe, 1982) }\end{array}$ \\
\hline
\end{tabular}

Bed thickness ranges between 1 and $3 \mathrm{~m}$. Erosional stacking patterns are frequent (Fig. 7). Numerous elongated clasts show an a axis type imbrication. Some have orientation parallel to the bedding plane (Figs. 7B, D and 8C). Small pebbles are dominant $(2-6 \mathrm{~cm}$ in diameter) while isolated large pebbles (cobbles of maximum diameter $10 \mathrm{~cm}$ ) are very rare. Matrix proportion is higher within this facies type.

Interpretation. The coarsening-upwards structures were rapidly deposited by a highly concentrated traction "carpet” (Lowe, 1982; Pickering et al., 1989). Internal dispersive pressures produced grain inversion inside high-density flows. As a consequence, large pebbles were deposited in the upper part of the surge (Postma et al., 1988). The entire flow process is heavily influenced by clast interaction. Some of the facies characteristics identified (e.g., inverse grading, clast orienation parallel to bedding, a axis imbrication) support this idea (Rees, 1968; Lewis et al., 1980; Surlyk, 1984).

Fining-upwards structures are formed when particle accumulation is influenced by their density (Walker, 1975). Large pebbles are concentrated at the base of such flows (Mutti, 1992). These clasts will form dense beds which act as traction "carpets". Dispersive pressure impacts the way sediments are distributed at the base of fining-upwards structures. As a consequence, suspension-derived sediments will accumulate in the upper parts of such sequences. Three main mechanisms define the accumulation of repetitive sets with basal coarsening-upwards and top fining-upwards trends. Deposition is controlled by concentrated flows (Mulder and Alexander, 2001), grain-by-grain mechanisms (Pickering et al., 1989) or highdensity turbidity currents (R2, R3 divisions of Lowe, 1982).

Alternating conglomerates, sandstones and microconglomerates - facies 3 (2-8 m)

Description. In this case, sandstone lenses and microconglomerates (thickness ranges from 15 to $30 \mathrm{~cm}$ ) are interbedded with conglomerate units (Fig. 9A, B, D). Conglomerate bed thickness ranges from 0.4 to $2.5 \mathrm{~m}$. They show rare coarsening/fining-upwards structures and frequent ungraded structures (Fig. 9A-D). The massive sequences contain ungraded isolated blocks. Conglomerate pebbles are poorly sorted. The sandstone beds contain small proportions of carbonate pebbles (Fig. 9B, D). Imbricated structures are common (Fig. 9B). Pebble dimension ranges from 5 to $15 \mathrm{~cm}$. Sandstone levels show irregular tops and bases. Gradational or erosional contacts separate these beds from the adjacent conglomerate/microconglomerate layers (Fig. 9D).

Observations. Small exposures were identified in the Grind area. Observations of exposures indicate the presence of fining-upwards structures with transitions from non-graded conglomerates to microconglomerates and sandstones (Fig. 9E, $\mathrm{F})$. The entire succession is interpreted as a transition from a debris flow to a concentrated/granular flow (Mulder and Alexander, 2001).

Interpretation. This facies type is defined by granulometric separation. Similar deposits were described by Hendry (1973: 135), Surlyk (1984, facies 13) and Kim et al. (1995, facies Gs). The entire depositional process is strongly linked to a slide or flow type mechanism. (Hendry, 1973). This local facies was accumulating on a distal inclined shelf slope. Sediment transport mechanisms are marked by a transition from debris flows to hyperconcentrated-concentrated flows (Sohn et al., 2002). Large volumes of transported material were delivered to the slope. As a consequence, rapid progradation occurred and sediments became unstable. Such an event can explain the presence of interbedded coarsening-upwards, fining-upwards and ungraded deposits in association with sandstones or isolated blocks (with a maximum diameter of $35 \mathrm{~cm}$ ). Sediments were deposited by debris, concentrated and hyperconcentrated flows under the action of high-density turbidity currents (Lowe, 1982; Mulder and Alexander, 2001).

\section{DISCUSSIONS}

The Aptian conglomerates contain moderate to well-sorted pebble-sized clasts. The existing matrix has a variable, claysandy to silty-sandy composition. Three main conglomerate facies types are present. They include ungraded conglomerates, 



Fig. 7. Facies 2 deposits - graded conglomerates (Brusturet area)

A - the basal part of a bed which directly overlies an erosional surface with a fining-upwards trend; small dimensions of component clasts; B - fining-upward and frequent imbrications (red circle) in a conglomerate bed which is delineated by erosional surfaces; C coarsening and fining-upwards conglomerates with imbricated pebbles (red frame) and erosional bases ( $\mathrm{C}$ - red arrows) that pass upward into amalgamated beds (E); D, E - details of image C (CU - coarsening upwards; FU - fining-upwards; A, B, D, E - erosional surface is marked by a dotted yellow line 


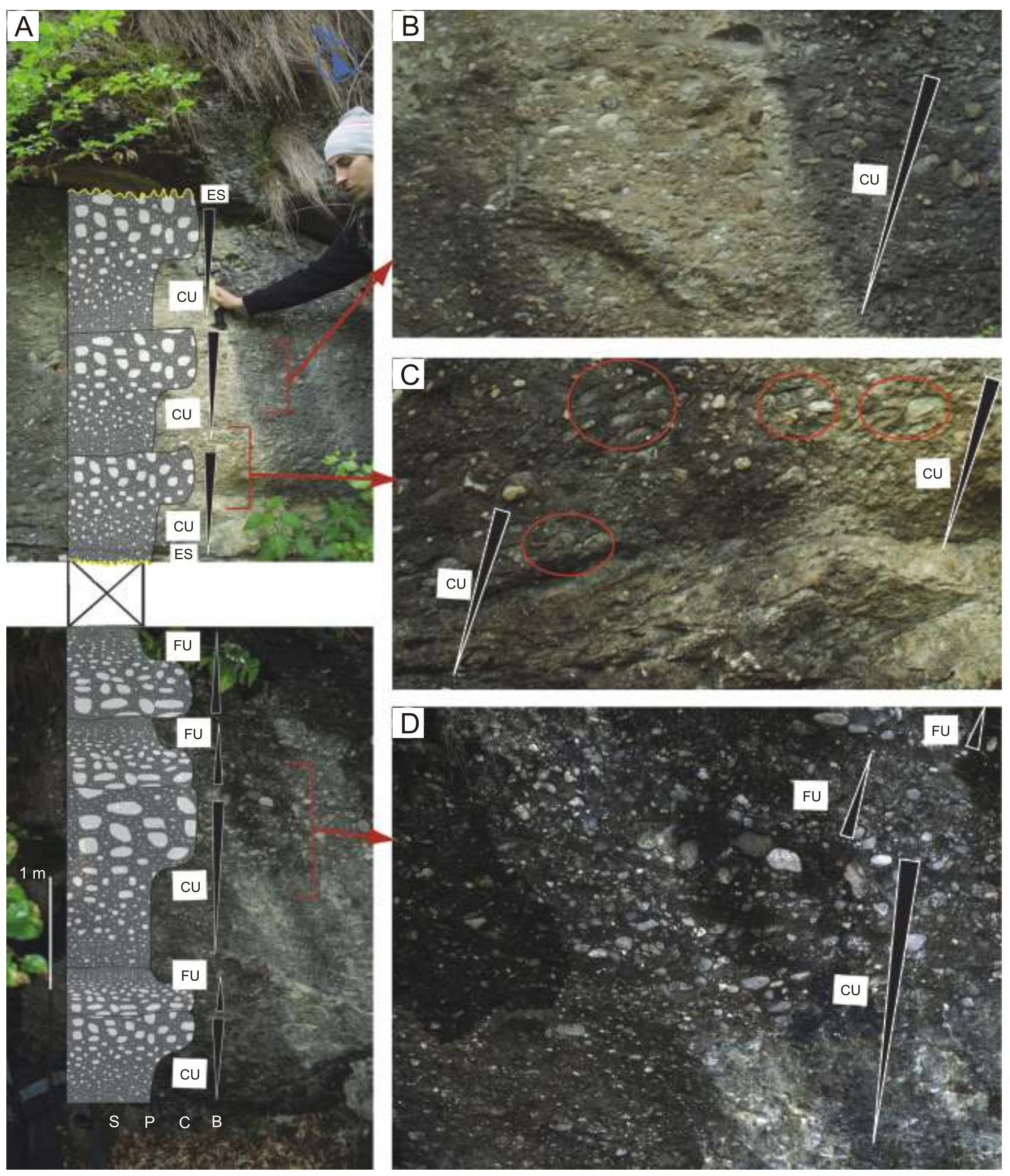

Fig. 8. Facies 2 (Brusturet area)

A - succession of Aptian conglomerates; one may observe several coarsening- and fining-upwards sequences within the same bed; B-D - detailed images from A; evident grading and pebble imbrication can be observed (C) (CU - coarsening upwards; FU - fining-upwards; ES - erosional surface) 

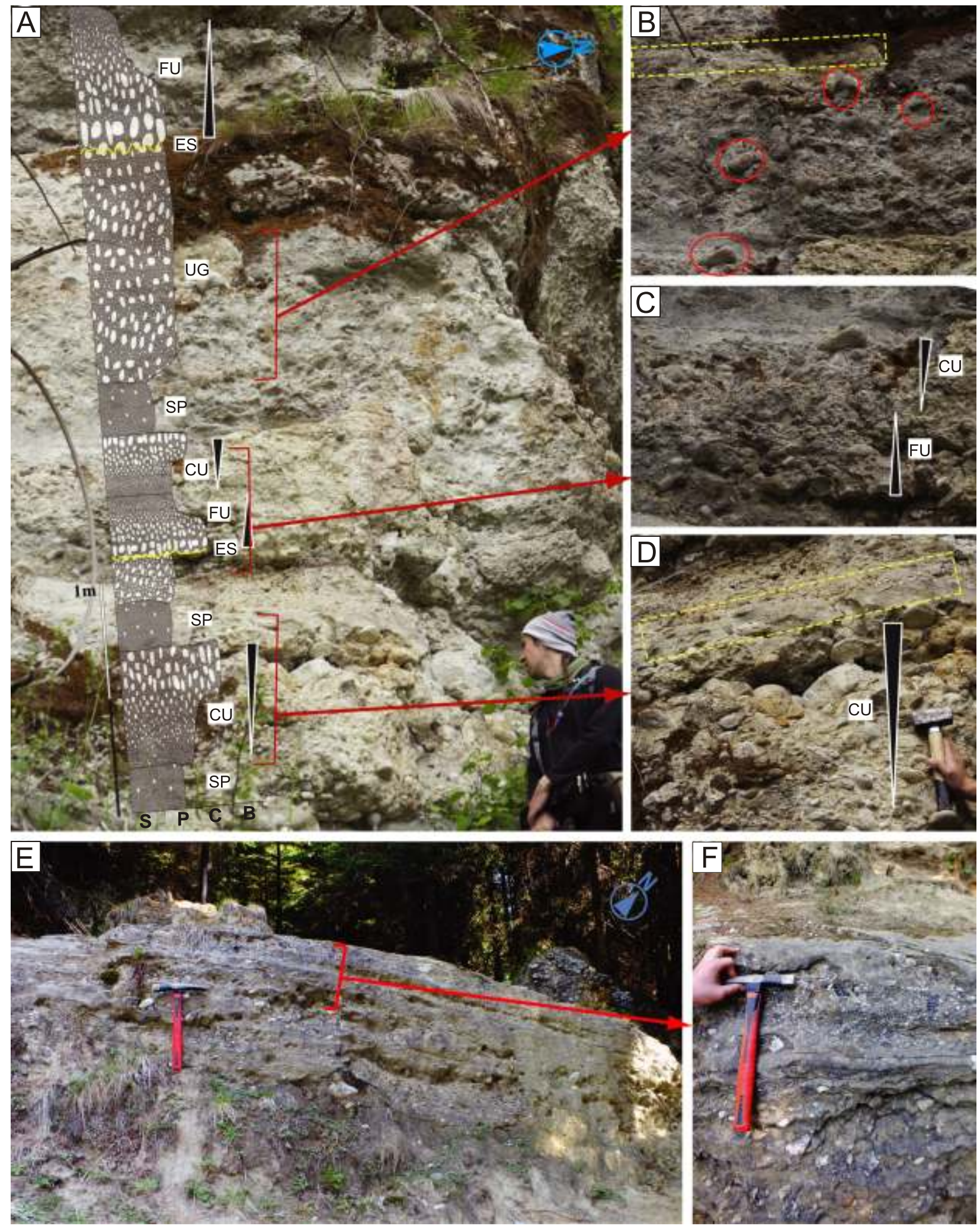

Fig. 9. Facies 3 (Pietricica)

A - alternating conglomerates, microconglomerates and sandstones (SP - conglomerate sandstone; CU - coarsening-upwards conglomerates, FU - fining-upwards conglomerates, UG - ungraded massive conglomerates, ES - erosional surface; red contour imbricated pebbles); B-D - detailed images from section A; E, F - fining-upwards structure; base to top transition is evident (from ungraded conglomerates to microconglomerates and sandstones) (F) (Grind - G2) 
fining- and coarsening-upwards conglomerates and alternating sandstones, conglomerates and microconglomerates. These sediments were deposited by debris, hyper-concentrated and concentrated gravitational flows (Table 1 and references therein). Such facies types characterize channel-fill deposits (e.g., Mastarelz, 1995; McCallum and Robertson, 1995). Detailed sections from Brusturet, Pietricica and Grind show ungraded and coarsening/fining-upwards conglomerates that were probably deposited by channel flows or as coarse overbank spill lobes. They are linked with the lateral progradation of mass flow deposits (Fig. 10). Palaeoflow direction measurements indicate the presence of dominant NE-SE, N-S and SW-NW oriented unidirectional submarine flows with specific sedimentological features (Fig. 10).

A subaqueous origin of these deposits is indicated by several diagnostic features. Thus, the matrix of breccia and conglomerate levels contains increased proportions of orbitolinids. In addition, clast grading is rarely observed in subaerial flows, and well-sorted, package-grouped structures are missing (Nemec and Steel, 1984). Grain size excludes the possibility of a tide-dominated depositional environment.
Several depositional scenarios were constructed by analysing the sedimentological features present. Three depositional models are defined. They include:

- a fault margin - fan-delta model (Fig. 11A),

- a submarine canyon/assemblage of channel-type flows, which fed a submarine fan (Fig. 11B),

$-\mathrm{a}$ combination of the first two versions. The genesis of the third model is strongly linked to Barremian-Cenomanian progressive tectonic events (Fig 11C).

(1) The conglomerate succession studied was deposited in a fan-delta type environment. This hypothesis is supported by the sedimentological features present (pebble size diameter, high frequency of coarsening- and fining-upwards structures, sorting) and the presence of an adjacent tectonically active area (Nemec and Steel, 1984; McPherson, 1987; Nemec and Steel, 1988). Continental alluvial fan deposits are absent from the studied region: Early Albian erosion has removed all trace of such sediments.

(2) Submarine canyon or channelized flow deposition is indicated by several factors. Sediments were routed by a series of

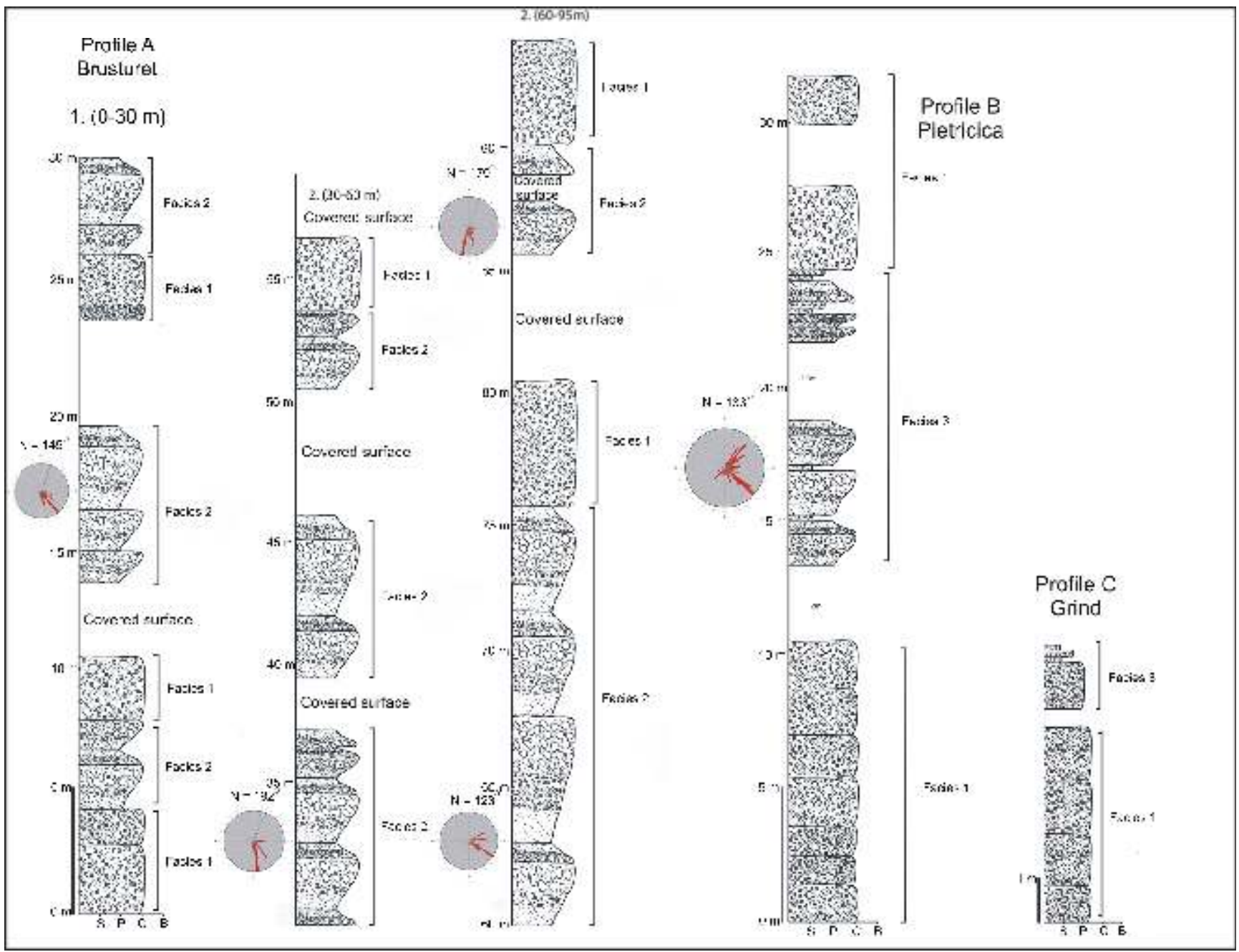

Fig. 10. Graphic representation of the most important sections (A - Brusturet, B - Pietricica, C - Grind)

Section $A$ indicates the alternation of facies types 1 to 3 , with a total thickness of $\sim 60 \mathrm{~m}$; it is dominated by facies types 1 and 2 representing mostly channel-fill deposits; sections $B$ and $C$ represent a combination of facies 3 and 1 ; they can be interpreted as deposited by channelized flows or as coarse lobes 

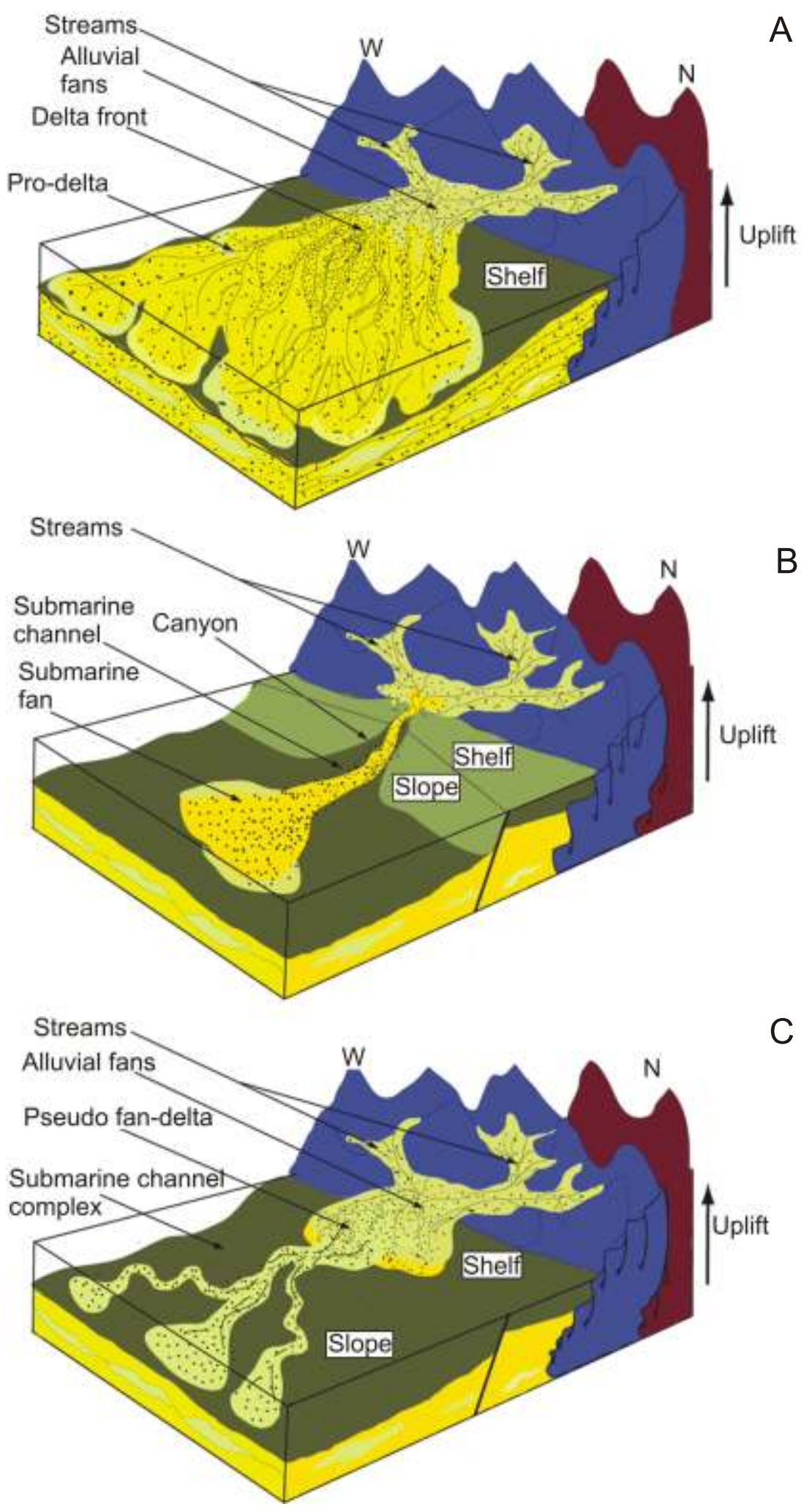

Fig. 11. Depositional environments - scenarios

A - inclined shelf fan delta; accelerated progradation is strongly influenced by significant sedimentary input; B - submarine canyon with unidirectional channel flows which were feeding a submarine cone; $\mathbf{C}$ - short-lived pseudo-fan-delta; strong sedimentary input and tectonic uplift due to advancing nappe fronts were transforming this system into an assemblage of channelized submarine flows 
channel flows and unidirectional currents through submarine canyons less than $10 \mathrm{~km}$ wide (e.g., Stow, 1986). Additional evidence comprises the presence of multiphase flow deposits which were generated by flow reactivation processes associated with unstable slopes or banks (Sohn et al., 2002).

(3) A third proposed sedimentological-kinematic model suggests the development of a small-scale pseudo-fan-delta on a slightly inclined shelf. The former structure evolved gradually into a submarine canyon/assemblage of channel-type flows, that fed a submarine fan. In this scenario, fault scarp gravel-dominated alluvial systems were probably feeding this delta (type A feeder system after Postma, 1990). This concept is supported by the tectonic history of the area. In this context, the region studied was located on a fault scarp, not far from an adjacent highland. Alluvial fan shelf progradation is furthermore indicated by the presence of abundant, well-preserved orbitolinids in the basal part of the succession (the matrix of the breccia and basal carbonate conglomerates). Shallow water carbonates were present in the provenance area. The rapid progradation of these deposits (as feeder channels) may have been triggered by the sudden uplift of the region or by high sedimentation rates. This uplift was associated with significant increase of siliciclastic input. In addition, the advancing nappes were producing large amounts of sediment.

As a consequence, feeder channels started to deliver sediment towards a series of submarine slope fans. This scenario is supported by the following arguments. Firstly, there is a significant increase of continental sediment input associated with the tangential character of the flows (Postma and Roep, 1985). Secondly, the matrix contains reworked orbitolinids which were reworked after resedimentation.

\section{RELATIONSHIP BETWEEN DETRITAL EVENTS AND TECTONIC ACTIVITY}

The Middle Jurassic-Cretaceous closure of the Neo-Tethys was followed by Cretaceous continental collision events (Schmid et al., 2008; Maţenco et al., 2010). Three main events define the accumulation of sedimentary deposits in the Piatra Craiului Massif. They include the Mid Jurassic transgression, the Kimmerdigian-Early Valanginian regression and the Late Valanginian transgression. Detrital sedimentation occurred mainly after the Late Valanginian. The Middle Late Aptian uplift of the entire region may be associated with the first tectonic events. Such movements determined the erosion of the sedimentary successions from the Făgăraş-Leaota-lezer Păpuşa region. The first part of the detrital succession contains Berriasian-Valanginian and Barremian-Aptian polymitic carbonate breccias (Ungureanu et al., 2015). Low-intensity shelf-slope debris flows were generated. They started to rework eroded material from proximal carbonate deposits. Concentrated and hyper-concentrated flow deposits began to develop. The Late Aptian was marked by intensified tectonic activity which triggered the uplift of adjacent areas. As a consequence, carbonate polymictic ortho- and paraconglomerates were deposited (Ungureanu et al., 2015). At some point the entire Middle Jurassic-Lower Cretaceous succession was exposed, including the crystalline basement (Ungureanu et al., 2017). Incipient tectonic activity was marked by the shelf slope deposition of the Gura Râului polymictic conglomerates. Finally, the Early Albian regression determined the subaerial exposure and erosion of the previous Aptian deposits.

\section{CONCLUSIONS}

The Piatra Craiului Syncline infill contains two types of conglomerates: the Aptian Gura Râului and the uppermost Albian-Cenomanian conglomerates. Three main facies types were separated within the Aptian conglomerates. They include: (1) massive conglomerates; (2) coarsening- and fining- upwards conglomerates; (3) alternating conglomerates, sandstones and microconglomerates. Typical channel morphologies are common for these facies associations. Several hypotheses were developed in order to define their depositional mechanisms. In these interpretations, fan-deltas, submarine canyons or submarine channel systems fed a submarine fan. The genesis of the Aptian detrital deposits is strongly linked with Early Cretaceous tectonic events since they were deposited after general uplift of the adjacent areas.

Acknowledgements. This work was possible due to the financial support of the Sectorial Operational Program for Human Resources Development 2007-2013, co-financed by the European Social Fund, under the project number POSDRU/159/1.5/S/132400 with the title "Young successful researchers - professional development in an international and interdisciplinary environment". It is also a contribution to the CNCS project PN-II-ID-PCE-2011-3-0025. The authors would like to thank H.J. Gawlick and the anonymous reviewers for their valuable suggestions which helped improve the quality of the manuscript.

\section{REFERENCES}

Aalto, K.R., 1976. Sedimentology of a mélange: Franciscan of Trinidad, California. Journal of Sedimentary Petrology, 46: 913-929.

Beccaro, P., Lazăr, I., 2007. Oxfordian and Callovian radiolarians from the Bucegi Massif and Piatra Craiului Mountains (Southern Carpathians, Romania). Geologica Carpatica, 58: 305-320.

Bernhardt, A., Jobe, Z.R., Lowe, D.R., 2011. Stratigraphic evolution of a submarine channelelobe complex system in a narrow fairway within the Magallanes foreland basin, Cerro Toro Formation, southern Chile. Marine and Petroleum Geology, 28 785-806.
Briceag, A., Jipa, D., Melinte, M.C., 2009. Early Cretaceous Deposits of the Ceahlău Nappe (Romanian Carpathian Bend Region). Geo-Eco-Marina, 15: 37-46.

Bucur, I.I., 1978. Microfacies of the white limestones from the northern part of Piatra Craiului Massif. Biostratigrafic constraints (in Romanian). Dări de Seama ale Şedinţelor Institutului Geologic şi Geofizic, 64 (for 1976-1977): 89-105.

Bucur, I.I., 1980. Rhaxella sorbyana (Blake) in Oxfordian radiolarites from Piatra Craiului Massif (in Romanian). Dări de Seamă ale Sedinţelor Institutului Geologic și Geofizic, 65 (3) (for 1977-1978): 31-35. 
Bucur, I.I., Săsăran, E., lacob, R., Ichim, C., Turi, V., 2009. Upper Jurassic shallow-water carbonate deposit from some Carpathian areas: new micropaleontological results. In: Proceedings of the 8th Simposion of IGGP 506, marine and nonmarine Jurassic: Global correlation and major global events, Bucharest, Romania, 28th August-9th September 2009 (ed. M. Popa): 13-14. International Geoscience Programme.

Bucur, I.I., Pascariu, L., Săsăran E., 2013. Calcareous algae from the olistholits at Poiana Zănoaga northern Piatra Craciului Syncline (Southern Carpathians, Romania). In: Proceedings of the 11th Workshop on alpine Geological Studies and 7th IFAA, Schladming-Dachstein, Austria, 9th-12th September 2013 (eds. H.-J. Gawlick and S. Missoni): 108-109. Berichte der Geologische Bundesanstalt, Wien.

Codarcea, A., 1940. Vues nouvelles sur la tectonique du Banat Meridional et du Plateau de Mehedinti. Anuarul Institutului Geologic Român, 20: 1-74.

Csöntos, L., Vörös., 2004. Mesozoic plate tectonic reconstruction of the Carpathian region. Palaeogeography, Palaeoclimatology, Palaeoecology, 210: 1-56.

DeCelles, P.G., Gray, M.B., Ridgway, K.D., Cole, R.B., Pivnik, D.A., Equera, N.P., Srivastava, P., 1991. Controls on synorogenic alluvial-fan architecture, Beartooth conglomerate (Palaeocene), Wyoming and Montana. Sedimentology, 38 : 567-590.

Dimitrescu, R, Patrulius, D., Popescu, I., 1971. Geological map of Romania, 1:50 000, sheet 110c (in Romanian) Institutul de Geologie şi Geofizică, Bucureşti.

Dimitrescu, R., Popescu, I., Schuster, A. C., 1974. Geological map of Romania, scale 1: 50.000, Bârsa Fierului Sheet (in Romanian). Institutul de Geologie şi Geofizică, Bucureşti.

Ethridge, F.G., Wescott, W.A., 1984. Tectonic setting, recognition and hydrocarbon potential of fan-delta deposits. In: Sedimentology of Gravels and Conglomerates (eds. E.H. Koster and R.J. Steel): 217-235. Canadian Society of Petroleum Geologists, Memoir 10, Calgary.

Fielding, C.R., LaGarry, H.E., LaGarry, L.A., Bailey, B.E., Swinehart, J.B., 2007. Sedimentology of the White clay Gravel Beds (Ogallala Group) in northwestern Nebraska, USA: structurally controlled drainage promoted by Early Miocene uplift of the Black Hills Dome. Sedimentary Geology, 202: 1-2.

Gawlick, H.-J., Missoni, S., 2015. Middle Triassic radiolarite pebbles in the Middle Jurassic Hallstatt Mélange of the Eastern Alps: implications for Triassic-Jurassic geodynamic and paleogeographic reconstructions of the western Tethyan realm. Facies, 61: 13

Gawlick, H.-J., Missoni, S., Sudar, M.N., Goričan, S., Lein, R., Stanzel, A.I., Jovanović, D., 2017. Open marine Hallstatt Limestones reworked in the Jurassic Zlatar Mélange (SW Serbia): a contribution to understanding the orogenic evolution of the Inner Dinarides. Facies, 63: 29

Gawlick, H.-J., Missoni, S., Sudar, M.N., Suzuki, H., Méres, S., Lein, R., Jovanović, D., 2018. The Jurassic Hallstatt Mélange of the Inner Dinarides (SW Serbia): implications for Triassic-Jurassic geodynamic and palaeogeographic reconstructions of the Western Tethyan realm. Neues Jahrbuch fur Geologie und Paläontologie, 288: 1-47.

Gherasi, N., 1962. The crystalline massif of Leaota (the northern part between Moeciu and Ghimbavului Valley) (in Romanian). Raport al Arhivelor Institutului Geologic, Bucureşti

Gherasi., N., Manilici, V., Dimitrescu, R., 1966. The geological and petrographical study of the Ezer-Păpuşa Massif (in Romanian). Anuarul Comitetului de Stat al Geologiei, 35: 47-104.

Grasu, C., Catană, C., Boboş, I., 1996. Petrography of the formations from the internal carpathian flysch (in Romanian). Editura Tehnică, Bucureşti

Grădinaru, M., Lazăr, I., Bucur, I.I., Grădinaru, E., Săsăran, E., Ducea, M.N., Andrăşanu, A., 2016. The Valanginian history of the eastern part of the Getic Carbonate Platform (Southern Carpathians, Romania): evidence for emergence and drowning of the platform. Cretaceous Research, 66: 11-42.
Hampton, M.A., 1975. Competence of fine-grained debris flows. Journal of Sedimentary Petrology, 45: 838-844.

Hendry, H.E., 1973. Sedimentation of deep water conglomerates in Lower Ordovician rocks of Quebec - composite bedding produced by progressive liquefaction of sediment? Journal of Sedimentary Petrology, 43: 125-136.

Higgs, R., 1990. Sedimentology and tectonic implications of Cretaceous fan-delta conglomerates, Queen Charlotte Islands, Canada. Sedimentology, 37: 83-103.

Jekelius, E., 1916. Daten uber den geologischen Bau des Bucsecs (Bucegi) und Csukas (Ciucaş). Jahresbericht der königlich ungarischen Geologischen Anstalt, f. 1915: 286-302.

Jekelius, E., 1938. Das Gerbige von Brasov. Anuarul Institutului Geologic al României, 19: 370-408.

Jipa, D.C., Ungureanu, C., Ion, G., 2013. Stratigraphy and tectonics of the uppermost Bucegi Conglomerate Formation (Albian Eastern Carpathians, Romania). Geo-Eco-Marina, 19: 1-13.

Kim, S.B., Chough, S.K., Chun, S.S., 1995. Bouldery deposits in the lowermost part of Cretaceous Kyokpori Formation, SW Korea: coesionless debris flows and debris falls on a steep-gradient delta slope. Sedimentary Geology, 98: 97-119.

Kostaki, G., Kilias, A., Gawlick, H.J., Schlagintweit, F., 2013. ?Kimmeridgian-Tithonian shallow-water platform clasts from mass flows on top of the vardar/axios ophiolites. Bulletin of the Geological Society of Greece, 67: 1-184.

Lewis, D.W., Laird, M.G., Powell, R.D., 1980. Debris flow deposits of early Miocene age, Deadman Stream, Marlborough, New Zealand. Sedimentary Geology, 28: 83-118.

Lowe, D.R., 1976. Grain flow and grain flow deposits. Journal of Sedimentary Petrology, 46: 188-189.

Lowe, D.R., 1982. Sediment gravity flows: II. Depositional models with special reference to the deposits of high-density turbidity currents. Journal of Sedimentary Petrology, 52: 279-297.

Mastalerz, K., 1995. Deposits of high-density turbidity currents on fan-delta slopes: an example from upper Visean Szczawno Formation, Intrasudetic Basin, Poland. Sedimentary Geology, 98: 121-146.

Maţenco, L., Krezsek, C., Merten, S., Schmid, S., Cloetingh, S., Andriessen, P., 2010. Characteristic of collisional orogens with low topographic build-up: an example from the Carpathians. Terra Nova, 22: 155-165.

McCallum, J.E., Robertson, A.H.F., 1995. Sedimentology of two fan-delta systems in the Pliocene-Plestocene of the Mesaoria Basin, Cyprus. Sedimentary Geology, 98: 215-244.

McPherson, J.G., Shanmugan, G., Moiola, R.J., 1987. Fan deltas and braid deltas: varieties of coarse-grained deltas. Geological Society of America, 99: 331-340.

Meszaros, N., Bucur, I., 1980. Oxfordian nannoplankton from the Piatra Craiului Massif (in Romanian). Muzeul Bruchental Ştiinţele Naturii, 24: 73-77.

Mircescu, C.V., Bucur, I.I., Săsăran, E., 2014. Dasycladalean algae from Upper Jurassic-Lower Cretaceaous limestones of Piatra Craiului Massif (South Carpathians, Romania) and their relationship to palaeonvironment. Studia UBB Geologia, 59: 5-27.

Mulder, T., Alexander, J., 2001. The physical character of subaqueous sedimentary density currents and their deposits. Sedimentology, 48: 269-299.

Murgoci, G., 1905. Contributions à la tectonique des Carpates Méridionels. Comptes Rendus de l'Académie des Sciences de Paris, 7: 60-84.

Murgoci, G., 1910. The Geological Synthesis of the South Carpathians. Comptes Rendus du XI-e Congrès Geologique International.

Mutti, E., 1992. Turbidite sandstones. Agip Special Publication, Milan.

Nemec, W., Steel, R.J., 1984. Alluvial and coastal conglomerates: their significant features and some comments on gravelly mass-flow deposits. In: Sedimentology of Gravels and Conglomerates (eds. E.H. Koster and R.J. Steel): 1-31. Canadian Society of Petroleum Geologists, Memoir 10, Calgary. 
Nemec, W., Steel, R.J., 1988. What is a fan delta and how do we recognize it. In: Fan Deltas: Sedimentology and Tectonic Settings (eds. W. Nemec and R.J. Steel): 3-13. Blackie and Son, Glasgow and London.

Olariu, C., Jipa, D.C., Steel, R.J., Melinte-Dobrinescu, M.C., 2014. Genetic significance of an Albian conglomerate clastic wedge, Eastern Carpathians (Romania). Sedimentary Geology, 299: $42-59$

Oncescu, N., 1943. Region de Piatra Craiului-Bucegi. Étude geologique. Anuarul Institutului Geologic al României, 12: 1-124.

Patrulius, D., 1969. Geology of the Bucegi Massif and the Dâimbovicioara Couloir (in Romanian). Editura Academiei Republici Socialiste Romania, Bucureşti.

Patrulius, D., Dimitriu, I., 1962. Mesozoic and neozoic terrains from the Dâmbovicioara Couloir between Rucăr and Bran (in Romanian). Raport Al Arhivelor Institutului Geologic, Bucureşti.

Patrulius, D., Dimitrescu, R., Popescu, I., 1971. Geological map of Romania, scale 1: 50.000 , Moieciu Sheet (in Romanian). Institutul de Geologie şi Geofizică, București.

Patrulius, D., Popa, E., Avram, E., Baltreş, A., Pop, G., Iva, M., Antonescu, E.M., Dumitrica, P., Iordan, M., 1980. Complex petrological and biostratigraphical study of the Jurassic and Neocomian formations from the Romanian Carpathians and Dobrudja. The mineral resources potential of the Leaota-Braşov-Perşani sector (in Romanian). Fieldwork report of the Geological and Geophysical Institute (theme 47/1979), Bucharest.

Pickering, K.T., Hiscott, R.N., Hein, F.J., 1989. Deep Marine Environments. Clastic Sedimentation and Tectonics. Unwin Hyman, London.

Pleș, G., Mircescu, C.V., Bucur, I.I., Săsăran, E., 2013. Encrusting micro-organism and bicrobial structures in Upper Jurassic limestones from the southern Carpathians ( Romania). Facies, 59: $19-48$.

Popescu, l., 1966. Contributions to the knowledge of the stratigraphy and geological structure of the Piatra Craiului Massif (in Romanian). Dări de Seamă ale Şedinţelor Institutului Geologic a României, 52: 157-176.

Popovici-Haţeg, V., 1898. Etude géologique des environs de Câmpulung et de Sinaia, Roumanie. These.

Postma, G., 1990. Depositional architecture and facies of river and fan deltas: a synthesis. In: Coarse Grained Deltas (eds. A. Colella and D.B. Prior): 13-27. International Association of Sedimentologists, Special Publication 10. Blackwell Scientific Publications, Oxford

Postma, G., Roep, T.B., 1985. Resedimented conglomerates in the bottomsets of Gilbert-type gravel deltas. Journal of Sedimentary Petrology, 55: 874-885.

Postma, G., Nemec, W., Kleinsphein, K.L., 1988. Large floating clasts in turbidites: a mechanism for their emplacement. Sedimentary Geology, 58: 47-61.

Rees, A.I., 1968. The production of preferred orientation in a concentrated dispersion of elongated and flattened grains. Journal of Geology, 76: 457-465.

Săndulescu, M., 1984. Geotectonic of Romania (in Romanian). Editura Tehnică, Bucuresti.
Săndulescu, M., 1994. Overview on Romanian geology. Romanian Journal of Tectonics and Regional Geology, 75: 3-15.

Săndulescu, M., Popescu, I., Săndulescu, J., Mihăilă, N. Schuster, A., 1972. Geological map of Romania, scale 1:50,000, Zărneşti Sheet (in Romanian). Institutul de Geologie şi Geofizică, București.

Schmid, S.M., Bernoulli, D., Fugenschuh, B., Maţenco, L., Schaefer, S., Schuster, R., Tischler, M., Ustaszewski, K., 2008. The Alpine-Carpathian-Dinaridic orogenic system: correlation and evolution of tectonic units. Swiss Journal of Geosciences, 101: 139-183.

Simionescu, I., 1897. Die Barremefauna im Quellengebiete der Dambovicioara (Rumanien). Verhandlungen der Kaiserlich koniglichen Geologischen Reichsanstalt, f. 1897: 131-134.

Sohn, Y.K., Choe, M.Y., Jo, H.R., 2002. Transformation from debrisflow to hyperconcentrated flow in a submarine channel (the Cretaceous Cerro Toto Formation, southern Chile). Terra Nova, 14: 405

Stanley, J.D., Hall, B.A., 1978. The Bucegi conglomerate: a Romanian Carpathian submarine slope deposit. Nature, 276: 60-64.

Stow, D.A.V., 1986. Deep clastic seas. In: Sedimentary Environments and Facies (ed. H.G. Reading): 399-442. Blackwell, Oxford.

Strzeboński, P., Kasprzyk, J.K., Olszewska, B., 2017. Exotic clasts, debris flow deposits and their significance for reconstruction of the Istebna Formation (Late Cretaceous-Paleocene, Silesian Basin, Outer Carpathians). Geologica Carpathica, 68: 562-582.

Surlyk, F., 1984. Fan-delta to submarine fan conglomerates of the Volgian-Wollaston Group, east Greenland. In: Sedimentology of Gravels and Conglomerates (eds. E.H. Koster and R.J. Steel). Canadian Society of Petroleum Geologists, Volume 10: 359-382. Calgary.

Toula, F., 1897. Eine geologische Reise in die transylvanischen Alpen Rumaniens. Neues Jahrbuch für Mineralogie, Geologie und Paläontologie, 1: 42-188.

Ungureanu, R., Săsăran, E., Bucur, I.I., Ungur, C.G., Mircescu, C.V., 2015. The Berriasian-Valanginian and Aptian deposits from the North Western part of the Piatra Craiului Massif: Stratigraphic relationships, facies and depositional environments. Acta Palaeontologica Romaniae, 11: 59-74.

Ungureanu, R., Săsăran, E., Bucur, I.I., Mircescu, C.V., Ungur, C.G., Ungureanu, A., 2017. The Cretaceous conglomerates from Piatra Craiului syncline (Sounth Carpathians, Romania): searching for the source area. Facies, 63: 30.

Walker, R.G., 1975. Generalized facies models for resedimented conglomerates of turbidite association. Geological Society of America Bulletin, 86: 737-748.

Walker, R.G., Mutti, E., 1973. Turbidite facies and facies association. In: Turbidites and Deep-Water Sedimentation (eds. G.V. Middleton and A.H. Bouma): 119-157. Pacific Section, Society of Economic Paleontologist and Mineralogist, Anaheim, Short Course Notes. 